\title{
勝者なき米国大学院課程の格付け
}

\section{US school ranking names no winners}

EMma MARRIS 2010 年 9 月 30 日号 Vol. 467 (510)

www.nature.com/news/2010/100928/full/467510a.html

待望の米国大学院の評価結果が公表された。

米国の大学院で最大規模の化学科を擁す るのは、カリフォルニア大学バークレー 校だ。大学院生は総勢 406 人 (2005 年 秋現在）もいる。また、最も長期間の生 態学課程を有するのは、チュレーン大学 （ルイジアナ州ニューオーリンズ）の生 態学・進化生物学科で、 $\mathrm{PhD}$ 取得まで に 8.5 年（中央値）を要する。遺伝学課 程で、教員が発表した論文 1 編当たり の平均被引用回数が最も多いのは、マサ チューセッツ工科大学 (ケンブリッジ) の 10.08 回で、他校を圧倒している。

それでは、物理学課程で最も優れてい る大学院はごこなのだろうか。今回公表 された報告書には、数多くの評価項目は 示されているのだが、どの大学院がナン バーワンなのか、という点だけが明確に 書かれていない。

2010 年 9 月 28 日、長い間待ち望ま れていた全米アカデミーの米国内 PhD 課程に関する調查研究である「米国の 研究学位課程に関するデータに基づい た評価 (A Data-Based Assessment of Research-Doctorate Programs in the United States)」の結果が公表された (go.nature.com/tqvokc 参照)。この評 価報告書は、各大学の大学院課程につい て「明確に順位を付した格付けをしない」 という点で注目に值する。

この調査研究はむしろ、十分に詳細な 比較を行うことで、入学願書の提出先を 学生が決めたり、大学の求人内容につい て求職者が判断したりする際の、助けと なることをめざしている。また、この報 告書に示された知見は、各州や各大学の
管理担当者が、予算支出の判断をするう えでの目安にもなると考えられる。

今回の報告書の公表は、資金問題のた めに当初より遅孔、米国学術研究会議 は、評価対象となることを望む大学に対 して、 1 課程当たり 1 万ドル (約 80 万円) を請求せざるを得なくなった。また、調 査研究の基礎デー夕は 5 年前のもので、 そのために報告書の影響力が限定的にな る可能性が生じている。しかし、この報 告書は、膨大な生データの宝庫であり、 それらを上手に利用すれば、具体的な論 点に関する解答が得られる。

また、今回の格付けは、前回の 1995 年版を含め、過去のどの格付けよりも
主観性が薄れている。「報告書を手早く 仕上げることよりも、正しい方法で作 成することのほうが大事だと考えまし た」。こう話すのは、この報告書の作成 委員会の委員長を務めるプリンストン大 学（ニュージャージー州）の天文学者 Jeremiah Ostriker だ。

この新しい格付けも、例えば、教員 1 人当たりの発表論文数や論文の被引用回 数といった定量的尺度に基づいている が、それらの尺度を 2 つ異なる方法 で重み付けして、格付けを導き出してい る。第一の方法（S ランキング）では、 各分野の研究者に対して、さまざまな尺 度の重要度の評価を依頼した。また第二 の方法（R ランキング）では、専門家が 各大学の大学院課程の格付けを行い、こ の格付けが再現されるように、さまざま な尺度の重み付けを統計解析によって求 めた。「今回の格付けは、さほど評判に は基づいていません。むしろ、評判を予 測させると思われる要因に基づいている わけです」と Ostriker は話す。

2つの方法で得られた格付けには、微 妙な違いがみられる（下図「格付けの一 例」参照)。例えば、大学院課程の規模

格付けの一例

2 つの研究分野における上位 5 課程のリスト。R ランキング（教員のアンケート調査から得られた 統計モデルに基づく格付け）とSランキング（教員が重要と考える判定基準に基づく格付け）では、 結果が異なっている。不確実性を排除するため、各課程の順位は、幅をもたせて示されている。

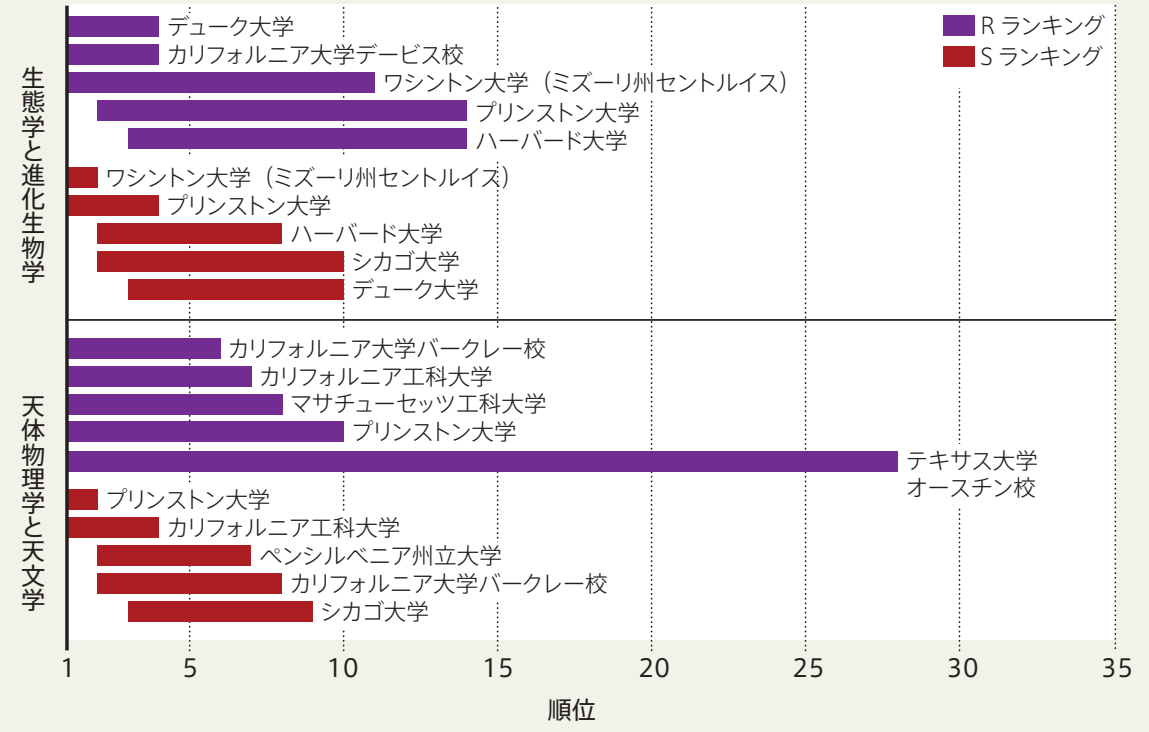


の重要性を強調した教員は少なかった が、PhD 取得者の多い課程を上位に格 付けする傾向がみられた。しかし、いず れの方法による格付けでも、意外なこと に、これ以外の尺度がほとんど重視され ていないのだ。「学生に対するきめ細か な指導、卒業後の学生の業績といった点 が重要なのは明らかですが、教員が最も 重視したのは、こうした点ではありませ んでした。研究成果のほうが大事だった のです」。こう Ostriker は説明する。

それぞれの大学院課程の順位は、平均 值ではなく、ある程度の幅をもたせて示 してあり、デー夕に含まれる不確実性や データの変動も表に出ている。今回の結 果を総体的に評するなら、「212大学の 5000 以上の大学院課程に関する 20 種 類の変数が含まれる膨大なデー夕」で あって、明白な勝者は示されていないと いうことだ。報告書はいう。「当委員会は、 博士課程の正確な格付けをするという構 想が誤りだと考える。各分野における『べ
ストの大学院課程』が宣言されることを 期待する読者はいるだろうが、本報告書 に、そのような記述はない」。

ラトガース大学大学院（ニュージャー ジー州ニューブランズウィック）学務部 副部長の Harvey Waterman は、今回の 評価研究で調查方法に関する助言を行っ たが、今後、あら探しも行われるだろう と予想する。例えば、「学際性」は、そ れぞれの大学院課程の担当教員のうち、 何人が併任であるかで評価されている。 ところが、もともと学際的な大学院課程 の場合には、担当教員は、その専門分野 にかかわらず、すべて専任であって、併 任ではないので、当然のことながら、評 点がゼロになってしまうのだ。

米国大学院審議会（ワシントン D.C.） の Debra Stewart 会長は、この報告書 が 2 種類の格付けシステムに基づいて おり、幅をもたせて評価結果が示されて いることについて、「ややこしいが非常 に健全」と評している。内容の異なる格
付け結果が併記されていることで、それ ぞれの大学院課程の優先事項に応じて、 異なった判定基準を用いるべきことが 明らかになっている、と Stewart は考 えるのだ。

多様性を誇る大学院課程では、学生の 多様性と教員に関係する尺度を重視する だろうし、今後も小さな規模を維持して いく予定の課程ならば、ほかの小規模な 大学院課程だけと比較したいと考えるだ ろう。データが少し古くなっている点に ついては、Stewart は「定期的な更新が なされない限りは重要性に変わりない」 と話す。

Ostriker は、データが更新されること を前提に、次のように話している。「数 年のうちに、最新の教員データを得て、 今回と同じ評価を行いたいと考えていま す。非常に短期間で変わるのは教員デー タだけですからね」。

(翻訳 : 菊川 要) 